\title{
FORMS OF CREATIVITY IN TRANSLATION
}

\author{
Lucía V. Aranda \\ University of Hawaii \\ laranda@hawaii.edu
}

\begin{abstract}
This paper explores the creative constructs utilized by translators in the reformulation of texts. As translation studies realigns the definition of translation vis-à-vis the original, a number of factors inform translations: the agency and subjectivity of the translator, as well as questions of form, and the more obvious social factors. This discussion addresses the articulation of creativity as a response to specific cases and repositions translation as part of a greater creative project.
\end{abstract}

Keywords: translation, creativity, difference, form.

\section{Introduction}

While the notion of creativity in translation has been considered with some suspicion, creativity is an inevitable aspect of the translation process. The apprehension surrounding creativity in translation is in part due to the indeterminacy of the term and in part to the frequent impression that creativity articulates less-than-exact translations. It has, in fact, been a neglected research topic in translation studies.

Creativity is an important task, which at an individual level involves problem solving and on a societal level leads to innovation. According to Sternberg and Lubart (2004: 3): "Creativity is the ability to produce work that is both novel (i.e. original, unexpected) and appropriate (i.e. useful, adaptive concerning task 
constraints)." In exploring this paradigm, the applications to translation are unmistakable.

Given that translation retraces the creative impulse of the original, both writer and translator are equally constrained by "the handling and crafting of the raw material of language" (Perteghella and Loffredo, 2007: 10). A commitment to the mere equivalence of this "raw material," too often the cornerstone of translation excellence, has the ability of erasing the most outstanding features of the source text and reducing the translation to an inferior copy, making it therefore unable to live up to the original. This mechanical function contrasts sharply with translation projects such as those of the Romans or the Romantics whose translators were viewed as possessing "creative genius" (Bassnett, 2004: 69), capable of enriching both literature and language. A translator's creativity is an essential element in the translation process as it incorporates "the original's mode of signification" (Benjamin, 1992: 79) and reconciles what might seem conflicting notions: fidelity and freedom. Translations undo the original (de Man, 1986) and in their rewriting require freedom to deal with the linguistic uniqueness of the source and target languages. It is only after translations are accepted for what they are - translations - that there can be greater freedom (Damrosch, 2003: 295).

In spite of the scant attention paid to creativity in translation, "[th]e shift away from grammatical and lexical contrasts and linguistic theories of translation and increased attention paid to pragmatic, discourse and sociolinguistic factors seem to have reinforced the emphasis on creativity" (Heltai, 2004: 58). Phenomena such as simplification, explicitation, or normalization are quantifiable but the conscious undertaking of these strategies versus the unconscious process of creativity reinforces the notion that creativity is inevitable in dealing with the asymmetries of translation.

Whereas 'create' and 'creation' are older terms, 'creativity' will not override "imaginative solutions" (Guilford [1959] in Pope, 2006: 20) to become a term in current usage until the second half of the twentieth century. In spite of this, it has become a pervasive 
term in many fields and encompasses all types of production: art, science, politics and marketing among others. When creativity is referenced or examined in translation studies, it is usually with regard to literary texts because "it is the nature of the literary text to invite creative engagement" (Boase-Beier, 2007: 55). And although technical or legal texts are not supposedly creative, factual ones still require a certain degree of creativity in their reformulation into another language (Mackenzie [1998] in Cho, 2006).

A cursory glance at creative strategies might reveal only processes of incorporation or elimination, as if translation were a reformulation where the choices were either compromise or haphazard invention. However, the creativity of original thoughts and divergent thinking needed in translation takes on many forms and as a linguistic device negotiates form and content.

Creativity, which responds to "conditions, biological and social, in ways that are healthful and 'healing' rather than harmful and destructive" (Pope, 2006: 76), is therefore a positive phenomenon. Discussed alongside issues of chance, psychological behaviors, divine intervention or personality traits, it manifests directly in concepts, ideas, techniques and language. Following is a look at an array of creative strategies and approaches translators take and how their "agency, subjectivity, intentionality, the management of discourse" (Hermans, 2007: ix) respond to social factors, form, and creative individualities. Mindful of Pope's words that what exists is difference and not strictly a 'common language', the "aim then would be not so much to 'speak the same language' as to develop facility - and facilities - in 'translating between languages'" (Pope, 2006: 190).

\section{Social factors: resistance and marketing}

Living as we do in a translated society translation brings into play social issues that range from resistance to marketing strate- 
gies. In certain contexts (and especially from a historical perspective) translation functions as an ethnographic tool, at first simply recording cultures but then spurring their transition towards homogeneity. It has now been established in translation scholarship that translation played a key role in colonial contexts. The translation projects of imperial powers such as Spain, Portugal, or Great Britain created versions of the colonized that erased the original and created another. Bacchilega and Arista (2007) chronicle how Hawaii at the end of the nineteenth century was undergoing its own colonization and argue that the linguistic situation reflected the political turmoil. English became the official language of public and private school instruction two years before political annexation in 1898, just as Pidgin (Hawaii Creole English, a mixture of English and the languages of the immigrants that developed on the plantations) was coming into its own. As Hawaiian began its decline, it would be appropriated by commercial and political interest groups. Simultaneously, translation into Hawaiian -supposedly to build literacy- was seen as a sign of acculturation. The newspapers became the focal point where the redefinition of Hawaii was to be played out and, as one daily explained openly in its first issue, the purpose was "to furnish from week to week such reading matters as may tend to develop and enlarge the Hawaiian mind, and enable Hawaiians to think, feel, act and live more like foreigners" (in Bacchilega and Arista, 2007: 175). One such story was a translation of Arabian Nights from the English (probably Lane's version). Already a transformation, He Kaao Arabia displaces original elements such as sexuality and replaces Shahrazad with a king who behaves according to Hawaiian values and morals. The incorporation of Hawaiian traditions such as chanting or hula into the tale could be understood to have possibly been a subversive act at the hands of the anonymous translator. While intrusive and moralizing, the creative re-imagining of the Persian story as a Hawaiian one can be considered resistance through localization (Bacchilega and Arista, 2007: 168). 
In Brazil, writers and translators drew on the metaphor of anthropophagy or cannibalism on the one hand to call attention to Europe's indebtedness to the New World and on the other to include the colonial in a universal dialogue. From Oswald de Andrade's 1928 Manifesto Antropófago ("Tupi or not tupi, that is the question") to the Campos brothers' translations, the Brazilian translation project of appropriating the literature from the West "to theorize and create a Brazilian poetics" (Vieira, 1999: 104) can be seen as both transformative and reciprocal.

Defamiliarization as a construct of creativity is readily apparent in the translation project of one of the world's most renowned writers on the politics of translation, Gayatri Spivak. Her now famous version of Devi's short story retranslated from "The Wet Nurse" to "Breast-giver" is, as Spivak (2003: 400) herself explains, "an example where attending to the author's stylistic experiments can produce a different text." To arrive at the author's signature style and neither neutralize the author's irony nor eliminate references to commodification of women as the first English version did, Spivak as translator relies on a disruption of the target language. The creativity Spivak is advocating resonates with Von Flotow-Evans' discussion of the influence of experimental feminist writing on translation practice. She suggests that translators "go beyond translation to supplement their work" and make up "for the differences between various patriarchal languages by employing wordplay, grammatical dislocations and syntactic subversion in other places in their texts" (Von Flotow-Evans, 1997: 24). In cases such as these, creativity embodies with full force its primary tenor of the development of new and original ideas.

All texts have particular characteristics whose essence must be conveyed in the translated text, and each genre has its own. Given that visual aspects of the theatre are able to verbalize non-textual signs or transform verbal signs into text, those of the theatre entail as well the decision of writing for the page (reader) or the stage (spectator). One approach is Eduardo De Filippo translation of The 
Tempest into an Italian regionalized voice. In doing so, he shifts Shakespeare into the theatrical tradition of a regional Italy and away from the Bard's own tradition (Perteghella, 2007: 109). Here creativity functions as a mechanism in the reallocation of cultural norms and presuppositions.

While the notion of creative marketing might be regarded with certain trepidation, translation is deeply involved in the business of globalization. From advertising to films to publishing, translation bridges cultural markets and shifts to accommodate global marketing trends. Film titles are made "attractive" in translation (Zatlin, 2005) and expanded to facilitate a lack of cultural references (Hawley, 2008), and books are shortened to ease a problematic reception. An assessment of the strategies behind creative translations and creative marketing reveals how the term 'creative' can become removed from its more positive connotations.

\section{Metatranslation: attention to form}

To a large degree, the limitations of translation are of a linguistic nature. But creativity is a construct that can overhaul the notion of untranslatability and give "voice to the intentio of the original not as reproduction but as harmony, as a supplement to the language in which it expresses itself" (Benjamin, 1992: 79). Foregrounded as translations, there are works such as Don Quixote or Memoirs of a Geisha which play upon the notion of the translation as a literary tool and use it as a literary strategy. In "Pierre Menard, Author of the Quixote" and "The Two Shores," both Borges and Fuentes respectively rely on their texts-as-translations to explore issues relating to the power of translation. In "Pierre Menard, Author of the Quixote," Borges anticipates relevance theory as he explores how the reader-translator informs a translation, in fact, any text, with personal and cultural history. As Menard sets out to recreate the Quixote, events after 1605 become part of the original. And so as 
in all original-translation dilemmas, Borges, who valued creative infidelities, considered how the original could in fact be unfaithful to the translation.

In Carlos Fuentes' novella "The Two Shores," based on Bernal Díaz del Castillo's 1632 narrative of the conquest of Mexico, Fuentes mistranslates Hernán Cortés as if through his own narrative he were able to rewrite the conquest of Mexico and undo history. In The Conquest of New Spain, Díaz del Castillo has Cortés reassure Cuauhtemoc through his interpreters: "Let his spirit and the spirit of his captains be at rest. For he should rule over Mexico and his provinces as before" (1963: 403-04). Knowing, as did Menard, how history played out the subsequent events, Fuentes translates the 'truth' and has Cortés instead say: "You'll never be able to walk again, but you'll accompany me on future conquests, crippled and weeping, as a symbol of continuity and the source of legitimacy for my enterprise" (1994: 10). In "The Two Shores" Fuentes explores the ethical and philosophical underpinnings of translation in the formation of truth and history. In the metanarrative of history "translation can reverse the order of things so as to reveal a subversive truth or desire that thwarts the surface meaning of the original" (Jay, 1997: 415). In this manner, translation is a rewriting which attempts an undoing of historicities.

Paralleling the manner in which native interpreters or lenguas interpreted between the colonizer and the colonized, the translations of Native American oral stories reevaluate the question of authorship and bring to the forefront issues of cultural transfer. Native American literature has reached canonical status in spite of or as it was thrust into a Euro-American literary setting (e.g. repetition so intrinsic to Native American storytelling was frequently omitted in translations into English). Early translators of Native American stories are doubly removed from the original, as they go from orality to literacy and from one language to another. According to Parker, author of The Invention of Native American Literature, the translation of Native American stories in fact "helped blur -or multiply- the lines between ethnology, folklore, and literature" 
(2003: 82). Many translations have four versions of the same story: a transcription, a transliteration, a literal translation and finally a more communicative one; a fifth, the video version, is possibly the solution to the veracity of the texts in translation. "Video offers a promising alternative; many viewers even imagine it as somehow truer than written texts" (Parker, 2003: 97).

Creative reworkings in translation can also lead to the invention of new languages and codes, as in the patois Christensen used in a story by Salarué or in the mix of archaic and modern forms employed by Venuti in I.U. Trachetti's work. But mostly, creative translators look to avoid the "loss of rhetorical silences of the original" (Spivak, 2003: 400) and a uniformity in translated literature that makes all translations sound alike. As Apter explains: "A 'politico-exotic' aesthetic taste has emerged, rapidly domesticating dissident writing and delocalizing non-Western literatures within a global pluralist continuum" (Apter, 2001: 7).

The history of translation is also the history of literary innovation. Translations introduce new concepts, new genres, new devices and mirror the shaping power of one culture on another. To approach translation from a "cognitive problem-solving orientation" (Lubart, 2004: 341), forms must be adapted and linguistic boundaries even disregarded. This is especially so in poetry, given the linguistic uniqueness and even literary divergencies the genre conjures across languages. Thus, translating forms which do not coincide, such as sonnets in English and Spanish or haikus in Japanese or Portuguese, are tasks which require creativity.

Texts foregrounded by visual aspects of an aesthetic or orthographic type require not only language viability but also attention to form for their recreation in translation. The transference of, for example, comics, rebus or concrete poetry into another language imposes restrictions of space, semantics, orthography, typography or effect and decisions ranging somewhere between literalness and communicativeness. Regardless, the response to forms should be analogous in translation (Rabassa, 1989). In the Pakistani The Geometry of God (2007) one of Uzma Aslam Khan's 
main characters is Mehwish, a young, blind girl whose older sister is teaching her to write: "I ask if it is 'eticut' or 'ex pearmint' and she gets angry. Then she tells me to call out the spellings and changes them to etiquette and experiment" (p. 48). To accommodate Mehwish's 'mistakes' in the English original, the translator, Cecilia Ceriani, recreated her writing in Spanish in the following manner: "Le pregunto cómo se escribe "de coro" o "espera miento" y se pone furiosa. Dice qe los deletree en voz alta y los cambia por decoro y experimento".

The articulation of creativity as playful and subversive (Pope, 2006: 27) is pervasive but never moreso than in constrained writing. One example is lipogrammatic writing which in eliminating a specific vowel requires a decidedly creative and resourceful hand in translation. George Perec's novel La Disparition, written without the letter $e$, has three English versions: $A$ Void by Gilbert Adair, Vanish'd by John Lee and A Vanishing by Ian Monk, neither of which use the letter $e$ either. The Spanish version, translated as El secuestro by Marisol Arbués et al, avoids the letter $a$-the most frequent letter in Spanish.

\section{Self-translations and beyond}

If personal involvement is a motivation that articulates creativity (Collins and Amabile, 2004: 297), the nature of self-translation is doubly motivating. "A narcissistic trial of authentication" according to Steiner (1998: 336), self-translations are some of the most interesting examples of creativity in translation as they bring together parallel creative processes and involve an elevated sense of ownership. Self-translations become second chances for authors to continue to correct, clarify and elaborate 'first drafts.' Rosario Ferré, whose novels are published in both Spanish and English as if they were originals, has declared that she writes in English and then translates into Spanish to "correct mistakes." In fact, the say- 
ings and idioms she adds in the Spanish translation of The House on the Lagoon (La casa de la laguna) revive the space for the actual story, realign the culture and recuperate the language of the source story. As Joyce helped translate "Anna Livia Plurabella" (which would ultimately become Finnegan's Wake) into Italian, he clarified parts of the text, incorporated more slang, and doubled and even tripled some of his plays on words, all in all creating a more daring version (Gentzler, 1993: 167). This capacity to be daring Levine (1991) calls subversive. In her opinion, authors who "abuse" language (e.g. Guillermo Cabrera Infante or Manuel Puig) will take a translation to another linguistic and stylistic level because, in fact, creativity is a translation strategy that goes hand in hand with language that is unpredictable or non-institutionalized (Wilss, 1998: 127).

While self-translation contends with linguistic recreation, the psychological involvement of the translator with the cultures and languages of the source and target texts is an aspect which should not be overlooked. For example, as Nabokov retraces his creative self, he positions his exile squarely between his languages, an action which allows him to "capture different modes of remembering" and to "rewrite memory" (Ordukhanyan, 2006). Self-translation as a translation of the self is on a par with identity-based literature. To reveal the self in translation, strategies may even consist of the inclusion of new material (Harvey, 2003).

The following three examples have to do with the notion of originality and innovation as creative constructs. (There are some authors such as Pope (2006) who differentiate between creativity, originality and innovation on the basis of unpredictability or cultural norms.) The first refers to the use of the paratexts by the translator as a means of extending the text to other modes of understanding. Such is the case of Dennis Tedlock's approach to translating Native American literature into English. In what might be considered un-Zuni like translations, the explanations of gestures, stage directions and other paralinguistic categories incorporated into Finding 
the Center: Narrative Poetry of the Zuni Indians have been actually deemed great literary innovations (Parker, 2003: 90).

The second and third examples illustrate the far-reaching consequences of creativity in translation. One is the interest of the West in Asian literature which spawned in part from Ezra Pound's highly personal and experimental translations of Li Po's Chinese poetry and would help define Modernism (Yao, 2002: 6). The other is the translation of stream of consciousness in China. Initially regarded as a tool to literary modernization by a handful of writers who looked to translation for creative constructs, in time it became a translation project supported by the Party. As Chinese letters turned from passive realism to a celebration of the individual, the quest for creativity in translation mirrored the political and economic changes in the country (Yifeng, 2008: 25-6).

\section{Conclusion}

Tottering between faithfulness and freedom and problem-solving and innovation, the scant research on creativity in translation means that it continues to be a fuzzy and indeterminate notion. However, it must be included in discussions of translations because as one of the unconscious strategies which re-creates the source text it takes on many forms and accounts for the individualities and unpredictability between versions.

Almost always a positive notion, creativity in translation realizes the shifts which stem from the need to reformulate linguistic, stylistic and cultural particularities. In accommodating this difference, creative strategies redo originals and reposition translations in a global society wavering between the specific and the universal. Exploring creativity as part of an internationalized aesthetics or cultural commodification legitimizes the individual subjectivities which inform translations and opens up further discussion on the creative constructs in translation. 


\section{Bibliography}

APTER, Emily. "On translation in a global market." Public Culture, 2001, n. 2: $1-12$.

ANDRADE, Oswald de. "Manifesto Antropófago". Revista de Antropofagia, 1928, n. 1. http://www.lumiarte.com/luardeoutono/oswald/manifantropof.html (accessed March 10, 2009).

BACCHILEGA, Cristina: ARISTA, Noelani. “The Arabian nights in the Kuokoa, a nineteenth-century Hawaiian newspaper: reflections on the politics of translation." In Marzolph, Ulrich. The Arabian nights in transnational perspective. Michigan: Wayne State University, 2007, p. 157-182.

BASSNETT, Susan. Translation Studies. London/New York: Routledge, 2004.

BENJAMIN, Walter. "The task of the translator." Trans. Harry Zohn. In SCHULTE, Rainer and BIGUENET, John. Theories of translation. Chicago: University of Chicago Press, 1992, p. 71-82.

BOASE-BEIER, Jean. "Loosening the grip of the text: theory as an aid to creativity." In PERTEGHELLA, Manuela and LOFFREDO, Eugenia. Translation and creativity. London: Continuum, 2007, p. 47-56.

CHO, Sang-Eun. "Translator's creativity found in the process of Japanese-Korean translation." Meta, 2006, n. 2: p. 378-388.

COLLINS, Mary Ann: AMABILE, Teresa. "Motivation and creativity." In STERNBERG, Robert J. Handbook of Creativity. Cambridge: Cambridge University Press, 2004, p. 297-312.

DAMROSCH, David. What is world literature? Princeton: Princeton University Press, 2003. 
DE MAN, Paul. The resistance to theory. Minneapolis: University of Minnesota Press, 1986.

DÍAZ DEL CASTILLO, Bernal. The conquest of New Spain. Trans. J. M. Cohen. London: Penguin Classics, 1963.

FUENTES, Carlos. "The two shores." In The orange tree. Trans. Alfred MacAdam. New York: Farrar, Straus and Giroux, 1994, p. 3-49.

GENTZLER, Edwin. Contemporary translation theories. Clevedon: Multilingual Matters, 1993.

HARVEY, Keith. "Translating camp talk: gay identities and cultural transfer." In VENUTI, Lawrence. The Translation Studies reader. London/New York: Routledge, 2003, p. 446-467.

HAWLEY, Chris. "Hollywood gets lost in translation." USA Today, August 1, 2008.

HELTAI, Pál. "Ready-made language and translation." In HANSE, Gyde, MALMKJAER, Kristen and GILE, Daniel. Claims, changes and challenges in Translation Studies. Amsterdam/Philadelphia: John Benjamins, 2004, p. 51-72.

HERMANS, Theo. "Foreword." In PERTEGHELLA, Manuela and LOFFREDO, Eugenia. Translation and creativity. London: Continuum, 2007, p. ix-X.

JAY, Paul. "Translation, invention, resistance: rewriting the conquest in Carlos Fuentes's 'The two shores.'” Modern Fiction Studies, 1997, n. 2: p. 405-431.

KHAN, Uzma Aslam. The geometry of God. India: Rupa and Co., 2007. La geometría de Dios. Trans. Cecilia Ceriani. Madrid: Alfaguara, 2009.

LEVINE, Suzanne Jill. The subversive scribe. Translating Latin American fiction. Washington: Graywolf Press, 1991. 
LUBART, Todd. "Creativity across cultures." In STERNBERG, Robert J. Handbook of creativity. Cambridge: Cambridge University Press, 2004, p. 339-350.

ORDUKHANYAN, Margarit Tadevosyan. "Strangers in stranger tongues: Vladimir Nabokov and the writing of exile, with reference to Joseph Conrad, Hakob Asadourian, and Roman Jakobson." PhD diss., Boston College, 2006. http:// escholarship.bc.edu/dissertations/AAI3209828/ (accessed May 28, 2009).

PARKER, Robert Dale. The invention of Native American literature. New York: Cornell University Press, 2003.

PERTEGHELLA, Manuela. "Poetry, music and transformation in the Gulf of Naples: a creative voyage of The Tempest." In PERTEGHELLA, Manuela and LOFFREDO, Eugenia. Translation and creativity. London: Continuum, 2007, p. 109-123.

and LOFFREDO, Eugenia. "Introduction." In PERTEGHELLA, Manuela and LOFFREDO, Eugenia. Translation and creativity. London: Continuum, 2007, p. 1-16.

POPE, Rob. Creativity: Theory, history, practice. London/New York: Routledge, 2006.

RABASSA, Gregory. "No two snowflakes are alike." In BIGUENET, John and SCHULTE, Rainer. The craft of translation. Chicago: University of Chicago Press, 1989, p. 1-12.

SPIVAK, Gayatri Chakravorty. "The politics of translation." In VENUTI, Lawrence. The Translation Studies reader. London/New York: Routledge, 2003, p. 397-416.

STEINER, George. After Babel. Oxford: Oxford University Press, 1998.

STERNBERG, Robert J.: and LUBART, Todd I. "The concept of creativity: prospects and paradigms." In STERNBERG, Robert J. Handbook of creativity. Cambridge: Cambridge University Press, 2004, p. 3-15. 
VON FLOTOW-EVANS, Luise. Translation and gender: translating in the "Era of Feminism." Ottawa: University of Ottawa Press, 1997.

VIEIRA, Else. "Liberating Calibans. Readings of Antropofagia and Haroldo de Campos' poetics of transcreation." In BASSNETT, Susan and TRIVEDI, Harish. Postcolonial translation. Theory and practice. London/New York: Routledge, 1999, p. 95-113.

WILSS, Wolfram. "Decision making in translation." In BAKER, Mona. Encyclopedia of Translation Studies. London/New York: Routledge, 1998, p. 57-60.

YAO, Steven G. Translation and the languages of Modernism. New York: Palgrave, 2002.

YIFENG, Sun. "Opening the cultural mind: translation and the modern Chinese canon.” Modern Langauge Quarterly, 2008, n. 2: p. 13-27.

ZATLIN, Phyllis. Theatrical translation and film adaptation. Clevedon: Multilingual Matters, 2005. 